\title{
THE BÔCHER MEMORIAL PRIZE
}

The establishment of the Bôcher Memorial Prize is a noteworthy departure in American Mathematical polity. It is believed that this is the first mathematical prize in our country to be given at regular intervals for research in pure mathematics.

The inception of the prize was due to Professor T. S. Fiske who, after the death of Maxime Bôcher in 1918, raised a voluntary fund for a permanent memorial of his work and services. This fund was turned over to the American Mathematical Society, and a special committee consisting of T. S. Fiske, C. N. Haskins, Dunham Jackson, O. D. Kellogg, and E. B. Van Vleck was appointed to consider its disposition. This committee reported to the Council the following resolutions which were adopted:

1. A prize of $\$ 100$ (later a larger sum) shall be awarded once in every five years for a notable research-memoir, published in the Transactions of the American Mathematical Society during the preceding five years by a resident of the United States or Canada. The prize shall be known as the Bôcher Memorial Prize.

2. Such interest of the Memorial Fund as is not used for the prize shall be added to the principal.

3 . The age of the recipient of the prize shall not be over forty years, and the prize shall not be awarded twice to the same person.

4. The first award of $\$ 100$ shall be made by a Committee of the Council for a memoir published during the period 19181922 , and shall be conferred at the annual or other designated meeting of the Society in 1923.

The suitability of the memorial will be apparent to all who are conversant with the history of American mathematics. Before many of the older generation imagined any immediate possibility of developing American mathematics to a perma- 
nent position of international importance, a group of the younger men had actually achieved this. It may be doubted whether another such formative period in American mathematics will ever recur. Professor Bôcher took his doctor's degree at the University of Goettingen in 1891, and on his return to Harvard University, became at once one of the outstanding figures in the new movement, thus stamping his impress on American mathematics when in its molten stage. When he died at the age of fifty-one, he left behind him a larger and more important aggregate of investigation in pure mathematics than had any preceding mathematician in America.

As the mathematical renaissance progressed, it became evident that the means for the publication of research in this country were altogether inadequate, and a new journal, the Transactions of the American Mathematical Society, was founded through the persistence of a small group of men, among whom Professor Bôcher was conspicuous. Because of his unusual fitness for editorial work he was chosen as its second editor-in-chief and served for two successive terms, 1907-1913. His colleagues on the editorial board can testify to Professor Bôcher's extraordinary capacity for editorial work,-his quick and accurate judgment of memoirs, his unselfish and lavish expenditure of time, his clearness and elegance of presentation.

In determining what disposition should be made of the fund, many possibilities were discussed, and the final form of the recommendation was due to a combination of considerations. Because of the eminence of the scientific work of Professor Bôcher and his power as teacher to stimulate investigation, it was felt that there could be no more fitting memorial than the use of the fund to encourage research. Also, in recognition of his editorial ideals and service, it was desired to connect the memorial with the Transactions and thus assist in raising the quality of mathematical production in America and Canada.

Unfortunately, the fund is not large, $\$ 1200$. In conse- 
quence, it was thought that a considerable portion of the interest must be set aside to secure the permanent usefulness of the fund. Hence it was recommended that the award of the prize should be made only once in five years, and that initially its amount should be limited to $\$ 100$. For the present the unique honor of its receipt must compensate for its inadequacy. Would that some friend of Professor Bôcher and American mathematics would increase the size of the prize and thereby its importance!

Under conditions prevailing in our colleges and universities an extraordinary amount of elementary instruction is necessary. This routine work is so important, so time-consuming and energy-exhausting as to distract the attention of our brightest young instructors from research. The first ten years following the doctor's degree are indeed very critical ones, and for this reson an age limit has been imposed on the prize. In recognizing particularly the younger men, the desire is to help keep American mathematics ever young. The age limit of forty years may be too high, but continued production is as essential as early production. It is hoped that the memoirs honored by the prize not only will have much intrinsic value but will exhibit also some of Professor Bôcher's lucidity and directness of style.

While general conditions have been framed for the prize, the administration and interpretation of the above resolutions are left to the successive committees of award.

Madison, Wisconsin, February 28, 1922.

EDWARd B. VAN Vleck. 